Acta vet. scand. 1981, 22, 153-161.

From the National Veterinary Institute, Oslo, Norway.

\title{
SEROLOGICAL INVESTIGATIONS OF MYCOBACTERIUM AVIUM AND M. AVIUM-LIKE BACTERIA ISOLATED FROM DOMESTIC AND WILD ANIMALS*
}

By

Finn Saxegaard

\begin{abstract}
SAXEGAARD, FINN: Serological investigations of Mycobacterium avium and $M$. avium-like bacteria isolated from domestic and wild animals. Acta vet. scand. 1981, 22, 153-161. - One hundred and two Mycobacterium avium and $M$. avium-like strains isolated from domestic and wild animals were submitted to serological typing by means of the agglutination method developed by Schaefer. Of the 82 porcine strains M. intracellulare serotype 8 dominated, followed in order of frequency by serotypes $1,4,2,10$ and 6 . Of the 20 strains originating from other animals 7 were typed as either serotype $2,3,8$ or 10 . The 3 strains isolated from wild birds were all serotype 2. As a considerable number of the wild animal strains were autoagglutinable, the suitability of the agglutination test for typing such strains is discussed.
\end{abstract}

M y cobacterium avium; M. intracellulare; serotyping; agglutination.

Along with the eradication and decreasing occurrence of Mycobacterium tuberculosis and $M$. bovis in various countries increasing interest has arisen in the so-called atypical, anonymous or nontuberculous mycobacteria. Several reviews relating to these bacteria have been published, most recently by Wolinsky (1979) who maintains that nontuberculous mycobacteria is the most appropriate term. Among these bacteria the M. avium-intracellulare complex with its 28 serotypes (Wolinsky) constitutes a large and comprehensive group, the epidemiology of which has been extensively elucidated since Schaefer (1965) introduced his serological typing procedure. Later the occurrence of these bacteria in animals has been reported from

- This investigation was supported by grants from the Norwegian Agricultural Research Council. 
several countries as summarized by J $\phi$ rgensen (1978), the most recent report of their occurrence being from Sweden (Bergman $\&$ Holmberg 1979). Of particular interest to the present study is the occurrence in various countries of the M. avium-intracellulare complex in pigs. This is best illustrated by Table 1 and will be discussed later.

T a b l e 1. Relative frequency (\%) of M. avium and M. intracellulare in pigs in various countries.

\begin{tabular}{llcc}
\hline Country & Reference & $\begin{array}{c}\text { M. avium } \\
\text { (Serotypes 1 to 3) }\end{array}$ & $\begin{array}{c}\text { M. intracellulare } \\
\text { (Serotypes 4 to 21) }\end{array}$ \\
\hline Denmark & $\begin{array}{l}\text { Jørgensen } \\
(1978)\end{array}$ & 87.1 & 10.5 \\
$\begin{array}{l}\text { Federal Republic } \\
\text { of Germany }\end{array}$ & $\begin{array}{l}\text { Meissner } \text { et al. } \\
(1978)\end{array}$ & 80 & 20 \\
France & $\begin{array}{l}\text { Meissner } \text { et al. } \\
(1978)\end{array}$ & 96 & 4 \\
Czechoslovakia & $\begin{array}{l}\text { Dubina et al. } \\
(1974)\end{array}$ & 84.5 & 15.5 \\
United States & $\begin{array}{l}\text { Thoen et al. } \\
(1975)\end{array}$ & 76.3 & 14.3 \\
Japan & $\begin{array}{l}\text { Yachida \& } \\
\text { Shimizu (1973) }\end{array}$ & 0 & 97.1 \\
$\begin{array}{l}\text { Republic of } \\
\text { South Africa }\end{array}$ & $\begin{array}{l}\text { Kleeberg \& Nel } \\
\text { (1973) }\end{array}$ & 19.3 & 60.5 \\
\hline
\end{tabular}

Since the eradication of bovine tuberculosis in Norway began, about the beginning of the present century, numerous isolations of $M$. avium have been made, mostly from cases of localized tuberculosis in pigs but also from cases of generalized tuberculosis in pigs and other domestic animals. The isolated strains have been tested biochemically, but so far no serological examination has been performed. Using the numbering system of Wolinsky \& Schaefer (1973), the results of the serological examination of $102 \mathrm{M}$. avium and M. avium-like strains isolated from domestic and wild animals are presented below.

\section{MATERIALS AND METHODS}

Strains

The number and origin of the strains are listed in Table 2.

Apart from 3 strains which were of Danish origin, the strains 
T a b l e 2. Origin and number of $M$. avium and $M$. avium-like strains investigated.

\begin{tabular}{lc}
\hline Species & Number of strains \\
\hline Cattle & 3 \\
Goat & 1 \\
Pig & 82 \\
Mink & 2 \\
Chicken & 3 \\
Roe-deer (Capreolus capreolus) * & 5 \\
Capercaillie (Tetrao urogallus) & 1 \\
Black grouse (Lyrurus tetrix) & 1 \\
Hazel hen (Tetrastes bonasia) & 1 \\
Goshawk (Accipiter gentilis) & 1 \\
Wood pigeon (Columba palumbus) ** & 2 \\
\hline Total & 102 \\
\hline
\end{tabular}

* 2 strains were of Danish origin.

* 1 strain was of Danish origin.

were isolated from animals submitted routinely for mycobacteriological examination at the National Veterinary Institute.

In pigs the tuberculous lesions were mostly of localized nature affecting the cervical or mesenteric lymph nodes, while in other animals the lesions were of generalized nature affecting most organs.

Biochemically most of the strains were characterized as $\mathbf{M}$. avium on the basis of the following tests: Reduction of nitrate (Virtanen 1960), catalase activity (Kubica et al. 1966), acid phosphatase activity (Käppler 1964), arysulphatase activity (Wayne 1961) and hydrolysis of Tween 80 (Wayne et al. 1964). Due to the extremely slow and sparse growth of the strains isolated from the roe-deer, hazel hen and wood pigeons these strains were characterized as $M$. avium-like on basis of their growth rate, nonchromogenicity and pathogenicity for experimental animals.

\section{Preparation of antigens}

With some modifications, the antigens were prepared as described by Schaefer (1979). Primary cultures on Petragnani's, L $\varnothing$ venstein-Jensen's or Stonebrink's medium were inoculated on slants of Middlebrook's 7H10 agar (Gibco) * with or without

* Gibco Bio-Cult Diagnostics Ltd., 3 Washington Road, Paisley PA34EP, Scotland. 
addition of 2 per cent mycobactin, depending on the mycobactin requirement of certain strains. In order to avoid contamination, tubes were preferred to plates, and pure cultures were checked by additional inoculation of blood agar plates. After incubation at $37^{\circ} \mathrm{C}$ for $3-5$ weeks, purity was again checked and the cultures were harvested in phosphate buffered saline (PBS, 0.01 $\mathrm{mol} / \mathrm{l}, \mathrm{pH} 7.0$ ) with the addition of 0.5 per cent phenol. As indicated by Yoder \& Schaefer (1971) the cultures were left at room temperature for 5 days in order to render the bacteria nonviable. The cultures were then washed 3 times in PBS. Using a Beckman model B spectrophotometer and $10 \mathrm{~mm}$ wide cuvettes the cultures were standardized at a wavelength of $525 \mathrm{~m} \mu$. Optical density (OD) was adjusted to 0.6.

Type strains of the $M$. avium-intracellulare complex * were prepared in the same manner.

\section{Preparation of antisera}

Sera were prepared by and large as described by Schaefer (1979). Rabbits were inoculated intravenously twice a week with $2 \mathrm{ml}$ of standardized type cultures which had been inactivated at $80^{\circ} \mathrm{C}$ for $30 \mathrm{~min}$. As preliminary investigations had shown that prolonged immunization resulted in a fatal hypersensitivity reaction, the rabbits were bled 5 days after the fourth injection and the sera were titrated against their homologous antigens. The titres of the sera ranged from 1:160 to $1: 2560$ and the sera were used unabsorbed. Sera were prepared against 2 strains of each of the 10 first serotypes in the system of Wolinsky \& Schaefer.

\section{Serotyping procedure}

Serotyping was performed according to Schaefer (1979) as a tube agglutination test. The sera were used at a dilution corresponding to twice their titre and 2 sera were used to represent each serotype. As no visible agglutination was observed after $3-4 \mathrm{~h}$ the results were read once after $24 \mathrm{~h}$. Complete agglutination was recorded as + , partial agglutination as $(+)$ and no agglutination as -

* Kindly supplied by Dr. J. B. Jørgensen of the State Veterinary Serum Laboratory, Copenhagen. 
When necessary the agglutinin absorption test was performed by concentrating the cross-reacting antigens 5 times and leaving them for absorption with equal amounts of serum diluted 1:10 for $1 \mathrm{~h}$ at $4^{\circ} \mathrm{C}$ before titration of the absorbed sera with homologous type specific antigens.

\section{RESULTS}

As the pig strains constituted the majority of the material, the typing of these strains is dealt with separately and shown in Table 3.

T a b l e 3. Distribution of serotypes of strains isolated from swine.

\begin{tabular}{|c|c|c|c|c|c|c|c|c|c|c|}
\hline & \multicolumn{7}{|c|}{ Serotype } & \multirow{2}{*}{$\begin{array}{c}\text { Not } \\
\text { typable }\end{array}$} & \multirow{2}{*}{$\begin{array}{c}\text { Auto- } \\
\text { aggl. }\end{array}$} & \multirow[b]{2}{*}{ Tota } \\
\hline & 1 & 2 & 4 & 6 & 8 & 9 & 10 & & & \\
\hline $\begin{array}{l}\text { Number } \\
\text { of strains }\end{array}$ & 15 & 6 & 10 & 1 & 33 & 3 & 6 & 5 & 3 & 82 \\
\hline$\%$ & 18.3 & 7.3 & 12.2 & 1.2 & 40.2 & 3.7 & 7.3 & 6.1 & 3.7 & 100 \\
\hline
\end{tabular}

Apart from 1 strain which reacted with only 1 serum, all strains reacted with both sera of 1 serotype. Agglutinin absorption was needed to type 3 strains. Table 3 shows that serotype 8 dominates $(40.2 \%)$, followed by serotype $1(18.3 \%)$, sero-

T a b l e 4. Distribution of number of strains isolated from animals other than swine.

\begin{tabular}{lccccccc}
\hline \multirow{2}{*}{ Species } & \multicolumn{3}{c}{ Serotype } & & $\begin{array}{c}\text { Not } \\
\text { typable }\end{array}$ & $\begin{array}{c}\text { Auto- } \\
\text { aggl. }\end{array}$ & Total \\
\cline { 2 - 6 } & 2 & 3 & 8 & 10 & & & 3 \\
Cattle & & & 1 & 1 & & 1 & 1 \\
Goat & & & 1 & & & 2 & 2 \\
Mink & & 1 & & & 1 & 1 & 3 \\
Chicken & & & & & & 5 & 5 \\
Roe-deer & 1 & & & & & & 1 \\
Capercaillie & 1 & & & & & 1 & 1 \\
Black grouse & 1 & & & & & & 1 \\
Gazel hen & & & & & & 2 & 2 \\
Wood pigeon & 3 & 1 & 2 & 1 & 1 & 12 & 20 \\
\hline Total & & & & & &
\end{tabular}


type $4(12.2 \%$ ), serotypes 2 and 10 (both $7.3 \%$ ), serotype 9 $(3.7 \%)$ and serotype $6(1.2 \%)$. Five strains $(6.1 \%)$ were not typable with the available sera and 3 strains $(3.7 \%)$ were autoagglutinable.

The typing of the other strains is presented in Table 4. Unfortunately 12 of the 20 strains were autoagglutinable and could not be typed. Of the typable strains the 2 cattle strains belonged to serotype 8 and 10 , the goat strain to serotype 8 , the chicken strain to serotype 3 and the capercaillie, black grouse and goshawk strains to serotype 2 .

\section{DISCUSSION}

\section{Porcine strains}

The results of this serotyping in Norway of porcine strains belonging to the $M$. avium-intracellulare complex indicate that M. intracellulare occurs more frequently than M. avium, $64.6 \%$ and $25.6 \%$, respectively. Comparison with similar investigations in other countries is best illustrated by viewing the present result in relation to Table 1. This table shows that in most countries, including Denmark, the Federal Republic of Germany, France, Czechoslovakia and the United States, M. avium has been the most frequently isolated agent from cases of tuberculosis in swine, while in Norway, Japan and South Africa M. intracellulare has been predominantly found. This is most clearly manifested in Japan where Yachida \& Shimizu (1973) found no cases of infection with M. avium. As indicated by Piening et al. (1972), the high frequency of $M$. avium in pigs in some countries is related to tuberculosis in chicken. Although chicken may constitute the primary source of infection, other domestic and wild birds may also serve as reservoirs, as mentioned by Jørgensen (1978). In Norway tuberculosis in chicken is rare. The source of infection for pigs must therefore be other animals or nonanimal sources. Recently, Songer et al. (1979) have drawn attention to sawdust and wood shavings used as bedding as a source of $M$. avium infection in pigs.

Among the various serotypes of M. intracellulare, serotype 8 was by far the most frequent in the present study. This is in agreement with Dubina et al. (1974) and Piening et al., who found serotype 8 in $11 \%$ and $18.7 \%$, respectively, in their material, and most strikingly with Yachida \& Shimizu, who recorded 
serotype 8 in $90 \%$ of all cases. The ubiquitous occurrence of $M$. intracellulare has been reviewed by Jørgensen and Saitanu \& Holmgaard (1977). It occurs in non-animal sources such as soil, water, dust and feedstuffs, and Piening et al. isolated serotype 8 from $28(42 \%)$ of 67 samples of sawdust. Although further investigations are needed, one cannot preclude the possibility that sawdust or other non-animal materials constitute reservoirs for the frequently occurring serotype 8 in Norwegian pigs.

\section{Other strains}

The limited number $(20)$ of these strains which is shown in Table 4, does not allow any general conclusions to be drawn about the frequency of serotypes in other domestic animals such as cattle, goats and chicken. As serotype 2 is the predominant strain in chicken (Jørgensen), the isolation of serotype 3 from a chicken in the present study may seem questionable. However, this strain reacted with sera of both serotype 2 and 3 , but was identified as serotype 3 after agglutinin absorption. Among the wild animal strains, only 3 bird strains were suitable for agglutination, but proved to be serotype 2 . This is in accordance with the investigations of $J \phi r g e n s e n$, who found 27 of 30 strains from wild animals to be serotype 2 .

Table 4 also shows that a considerable number of strains from other species than the pig were autoagglutinable and this particularly applies to the wild animal strains ( 8 out of 11 strains). Although the present material is limited, the author's experience is that strains from wild animals are usually extremely dry, crisp, autoagglutinable and therefore completely unsuitable for agglutination. In comparison, Dubina et al. found $10 \%$ of cattle strains to be autoagglutinable and maintain that due to this disadvantage the suitability of the agglutination test is somewhat reduced.

Conclusively, Schaefer's serotyping procedure which in the present study has been applied for the first time in Norway, has proved to be of significant value in typing strains of the $M$. avium-intracellulare complex which occurs frequently in pigs in this country. It is hoped that a greater number of typable $M$. avium-like strains from other domestic and wild animals will be available for future investigations, and that the method will prove to be equally valuable in typing such strains. 


\section{ACKNOWLEDGEMENTS}

The author is indebted to Dr. J. B. Jørgensen, the State Veterinary Serum Laboratory, Copenhagen, not only for supplying the type strains and 3 of the wild animal strains, but also for valuable advice during the investigations. Mrs. Margrethe Jacobsen is thanked for skillful technical assistance.

\section{REFERENCES}

Bergman. $R$. \& $O$. Holmberg: Occurrence and characterization of "avium-like" mycobacteria isolated from animals in Sweden. Acta path. microbiol. scand. Sect. B 1979, 87, 363-369.

Dubina, J., L. Sula, M. Kubin \& J. Varekova: Incidence of M. avium and M. intracellulare in cattle and pigs. J. Hyg.-Epidem. (Praha) $1974,18,15-21$.

Jørgensen, J. B.: Serological investigation of Mycobacterium avium and Mycobacterium intracellulare isolated from animal and non-animal sources. Nord. Vet.-Med. 1978, 30, 155-162.

Käppler, W.: Uber die Verbreitung einer „sauren“ Phosphatase innerhalb der Gattung Mycobakterium. (On the occurrence of "acid" phosphatase in mycobacteria). Beitr. Klin. Tuberk. 1964, 129, $210-213$.

Kleeberg, H. H. \& E. E. Nel: Occurrence of environmental atypical mycobacteria in South Africa. Ann. Soc. belge Med. trop. Parasit. Mycol. 1973, 53, 405-418.

Kubica, G. P., W. D. Jones, V. D. Abbott, R. E. Beam, J. O. Kilburn \& J. C. Carter: Differential identification of mycobacteria. I. Tests on catalase activity. Amer. Rev. resp. Dis. 1966, 94, 400-405.

Meissner, G., J. Viallier, G. Viallier \& D. Coullioud: Identification sérologique de 1590 souches de Mycobacterium avium isolées in France et en Allemagne fédérale. (Serological identification of 1590 strains of Mycobacterium avium isolated in France and the Federal Republic of Germany). Ann. Microbiol. (Inst. Pasteur) 1978, 129A, 131-137.

Piening, C., W. Anz \& G. Meissner: Serotyp-Bestimmungen und ihre Bedeutung für epidemiologische Untersuchungen bei der Schweinetuberkulase in Schleswig-Holstein. (Serotype determination and its significance for epidemiological studies of porcine tuberculosis in Schleswig-Holstein). Dtsch. tierärztl. Wschr. 1972, 79, 316-321.

Saitano, K. \& P. Holmgaard: An epizootic of Mycobacterium intracellulare serotype 8 infection. Nord. Vet.-Med. 1977, 29, 221226.

Schaefer, W. B.: Serologic identification and classification of the atypical mycobacteria by their agglutination. Amer. Rev. resp. Dis. $1965,92,85-93$.

Schaefer, W. B.: Serological identification of atypical mycobacteria. In Bergan, T. \& J. R. Norris: Methods in Microbiology vol. 13, Academic Press, London 1979, pp. 323-343. 
Songer, J. G., E. J. Bicknell \& C. O. Thoen: Epidemiological investigation of swine tuberculosis in Arizona. Canad. J. comp. Med. $1979,44,115-120$.

Thoen, C. O., J. L. Jarnagin \& W. D. Richards: Isolation and identification of mycobacteria from porcine tissues. A three-year study. Amer. J. vet. Res. 1975, 36, 1383-1386.

Virtanen, S.: A study of nitrate reduction by mycobacteria. Acta tuberc. scand. 1960 , suppl. 48.

Wayne, L. G.: Recognition of M. fortuitum by means of a three-day phenolphtalein test. Amer. J. clin. Path. 1961, 36, 185-187.

Wayne, L. G., J. R. Doubek \& R. L. Russel: Classification and identification of mycobacteria. I. Tests employing Tween 80 as substrate. Amer. Rev. resp. Dis. 1964, 90, 588-597.

Wolinsky, E.: Nontuberculous mycobacteria and associated diseases. Amer. Rev. resp. Dis. 1979, 119, 107-159.

Wolinsky, E. \& W. B. Schaefer: Proposed numbering scheme for mycobacterial serotypes by agglutination. Int. J. system. Bact. 1973, $23,182-183$.

Yachida, S. \& K. Shimizu: Studies on atypical mycobacteria isolated from tuberculous lesions of the mesenteric lymph nodes of slaughtered pigs. Jap. J. vet. Sci. 1973, 35, 459-471.

Yoder, W. D. \& W. B. Schaefer: Comparison of the seroagglutination test with the pathogenicity test in the chicken for the identification of Mycobacterium avium and Mycobacterium intracellulare. Amer. Rev. resp. Dis. 1971, 103, 173-178.

\section{SAMMENDRAG}

Serologiske unders $\phi k e l s e r$ over Mycobacterium avium og M. aviumliknende bakterier isolert fra domestiserte og ville dyr.

Ett hundre og to Mycobacterium avium- og M. avium-liknende stammer ble typet serologisk ved hjelp av agglutinasjonsmetoden utarbeidet av Schaefer. Av 82 stammer isolert fra gris dominerte $M$. intracellulare serotype 8 etterfulgt $i$ frekvens av serotype $1,4,2,10$ og 6. Av 20 stammer isolert fra andre dyr ble 7 typet som serotype 2, 3,8 eller 10. De 3 stammene isolert fra ville fugler tilh $\varnothing$ rte alle serotype 2. Da et betydelig antall stanmer isolert fra ville dyr var autoagglutinable, er anvendeligheten av agglutinasjonsmetoden for typing av slike stammer blitt diskutert.

(Received December 4, 1980).

Reprints may be requested from: Finn Saxegaard, the National Veterinary Institute, P.0. Box 8156, Dep., Oslo 1, Norway. 